\title{
Below normal birth weight in the Northwest part of Ethiopia
}

\author{
Wale Kumlachew ${ }^{1}$, Nega Tezera ${ }^{2}$ and Aklilu Endalamaw ${ }^{2 *}$
}

\begin{abstract}
Objectives: Low birth weight is one of the global agendas that have an impact on the short and long-term health status. A cross-sectional study from March 1 to April 1, 2018 was conducted. 381 mother-newborn pairs were participated. This study aimed to assess the prevalence and associated factors of low birth weight in the Northwest part of Ethiopia.

Results: The prevalence of low birth weight was 14.9\% (95\% Cl 11.7-18.9). Being preterm [adjusted odds ratio $(A O R)=4.1 ; 95 \% \mathrm{Cl} 1.7-9.9]$, absence of ante-natal care follow-up ( $A O R=3.4 ; 95 \% \mathrm{Cl} 1.2-9.5$ ), malaria attack during pregnancy ( $A O R=4.2 ; 95 \% \mathrm{Cl} 1.6-11.1)$, anemia during pregnancy $(A O R=2.6 ; 95 \% \mathrm{Cl} 1.03-7.0)$, and lack of iron supplementation $(A O R=4.0 ; 95 \% \mathrm{Cl} 1.3-12.6)$ were predisposing factors to low birth weight. On the other hand, infants born from employed mothers ( $A O R=0.1 ; 95 \% \mathrm{Cl} 0.01-0.92$ ) were less likely to born with below normal birth weight. The prevalence of low birth was high as compared to WHO estimation.
\end{abstract}

Keywords: Birth weight, Newborn, Ethiopia

\section{Introduction}

Low birth weight (LBW) is one of the reliable indicators and monitoring parameters of maternal and child health programs [1]. According to the world health organization (WHO) definition, LBW considered if weight at birth less than $2500 \mathrm{~g}$ [2].

Being below normal birth weight is the greater risk for different severe and life-threatening health complications. Notably, hypothermia, hypoglycemia, birth asphyxia, anemia, impaired nutrition, and respiratory problems are the major complications of LBW [3].

It is possible to prevent $\mathrm{LBW}$ prior to its occurrence. Accordingly, WHO sets a 30\% reduction of LBW by 2025 through providing affordable, accessible, and appropriate healthcare services [4]. Accessing maternal education, expansion of antenatal care service, promoting planned pregnancy, preventing teenage pregnancy, increasing

\footnotetext{
*Correspondence: yaklilu12@gmail.com

${ }^{2}$ Department of Pediatric and Child Health Nursing, School of Nursing, College of Medicine and Health Sciences, University of Gondar, Gondar, Ethiopia

Full list of author information is available at the end of the article
}

skilled birth attendants, and improving prenatal care services are implementing to prevent LBW [5].

Despite different healthcare services, LBW is continuing to be one of the important public health problems worldwide. Correspondingly, $15 \%$ to $20 \%$ of all births worldwide were LBW in 2014 [4]. It is also reported in Nepal (22.3\%) [6], Nigeria (6.3\%) [7], and Kenya (12.3\%) [8]. Similarly, the prevalence of LBW is vary in different geographical areas of Ethiopia; 17.4\% in Gondar Ethiopia [9], 11.1\% in Southwest Ethiopia [10], and 9.9\% in Northern Ethiopia [11]. The social and economic [12], maternal and infant-related factors of LBW are identified from other previous studies [12, 13].

There was no study found in the current study area related to LBW. Even if there are studies in other parts of the country, it cannot be represent the current study area due to the difference in demographic, socio-cultural, and other health coverage status.

Therefore, we aimed to assess the prevalence of low birth weight and its associated factors in the Northwest part of Ethiopia.

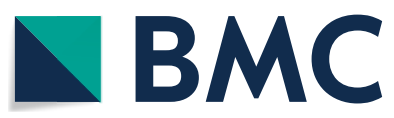

C The Author(s) 2018. This article is distributed under the terms of the Creative Commons Attribution 4.0 International License (http://creativecommons.org/licenses/by/4.0/), which permits unrestricted use, distribution, and reproduction in any medium, provided you give appropriate credit to the original author(s) and the source, provide a link to the Creative Commons license, and indicate if changes were made. The Creative Commons Public Domain Dedication waiver (http://creativecommons.org/ publicdomain/zero/1.0/) applies to the data made available in this article, unless otherwise stated. 


\section{Main text \\ Methods \\ Study design, period, setting, and population}

An institution based cross-sectional study was employed from March 1 to April 1, 2018, at two hospitals in the delivery clinics of Northwest part of Ethiopia. These hospitals are Assosa and Pawi general hospitals, where the majority of the population of the region gets healthcare services. Based on the current Ethiopian government classification, these hospitals are found in the Benishangul-Gumuz Region, which is located $632 \mathrm{~km}$ far from Addis Ababa. Based on the 2007 Census conducted by the Central Statistical Agency of Ethiopia [14], the Benishangul-Gumuz Region has a total population of 784,345. Of which, 398,655 were men and 385,690 were women. A lower percentage $(13.51 \%)$ of the population were urban inhabitants [15]. According to 2016 EDHS report, the fertility rate of the region was $4.4 \%$ [16].

All mother-neonate pairs were the study population.

\section{Sample size and sampling technique}

The sample size is calculated using single population formula

$$
\left(n=(z a / 2)^{2} \mathrm{pq} / \mathrm{d}^{2}\right) .
$$

where $\mathrm{n}$ is the desired sample size, $\mathrm{Z}$ is the standard normal distribution 1.96, $\mathrm{P}$ is the prevalence of low birth weight in Gondar Ethiopia (17.4\%) [9], q is the proportion of the target population without the problem $(1-\mathrm{p})$, $\mathrm{d}$ is the $4 \%$ margin of error, $\mathrm{n}=(1.96)^{2}(0.174)(0.826) /$ $(0.04)^{2}=346$.

Considering $10 \%$ non-response rate, the total sample size is $346+35=381$.

Participants were selected using proportional allocation; 241 samples from Assosa, and 140 from Pawi Hospital from the total of 710 mother-infant pairs. A systematic random sampling technique was conducted. Each participant was selected using $(k \approx 2)$ after providing a number to pregnant mothers attending delivery room from day one to the end of data collection. In situations, where a respondent did not agree or not met the inclusion criteria, the next random position would be considered.

\section{Operational definition}

Below normal birth weight: neonates whose birth weight less than $2500 \mathrm{~g}$.

\section{Data collection tools and procedures}

Data was collected using a structured and pre-tested questionnaire, measurement, and chart review. The questionnaire was adapted from the Ethiopian demographic and health survey [16] and other literature. The questionnaire had three parts. The first part contains socio-demographic characteristics, the second part contains infant-related variables, and the third part contains maternal and obstetric-related variables.

Two diploma midwives and nurses who were working outside the study area collected the data. The weight of the newborn was measured after $30 \mathrm{~min}$ of delivery using a balanced weight scale. Maternal height was measured against a wall height scale to the nearest centimeter. Maternal weight was measured by beam balance to the nearest kilogram. Participants' medical charts were reviewed to take some important variables like maternal hemoglobin level.

\section{Data processing and analysis}

Firstly, data were checked for completeness and inconsistencies. The collected data was entered into Epi-data version 4.2.0.0. and then exported to STATA version 14.0 for analysis. The socio-demographic distributions of the participants were described using descriptive statistics. Binary logistic regression analysis was applied. The multivariable logistic regression analysis was done for variables with a P-value less than 0.25 in the bivariable analysis. Those variables with $\mathrm{P}$-value $\leq 0.05$ were claimed as significantly associated factors of LBW.

\section{Ethical considerations}

Ethical clearance was obtained from the School of Nursing on behalf of the University of Gondar Institutional Ethical Review Committee. Written permission was taken to both Assosa and Pawi General Hospitals' manager. Then, each respective manager wrote permission letter to the focal persons. Name or identification number of study participants was not recorded. Participant data was used only for the study purpose.

\section{Result \\ Maternal socio-demographic characteristics}

Three hundred seventy-five mother-neonate pairs have participated with a response rate of $98.4 \%$. Mean age of mothers in this study was $27.19 \pm 5.13$ years. Of these, $72.53 \%$ mothers were between the ages of 20-35 years. About $45.6 \%$ of mothers were housewives. Regarding the residence, $33.33 \%$ were rural dwellers. The majority (41.87\%) of mothers were diploma and above. The majority (30.13\%) were Amhara ethnic group (Table 1 ).

\section{Association between LBW and socio-demographic characteristics}

From the study participants, 56 were LBW, which makes the prevalence to be $14.93 \%$. Mothers who were 
Table 1 Maternal demographic characteristics of mothers Assosa and Pawi hospitals, Northwest Ethiopia, 2018

\begin{tabular}{|c|c|c|}
\hline Variable & Frequency & Percent \\
\hline \multicolumn{3}{|l|}{ Maternal age (years) } \\
\hline $15-20$ & 40 & 10.67 \\
\hline $20-35$ & 272 & 72.53 \\
\hline$>35$ & 63 & 16.80 \\
\hline \multicolumn{3}{|l|}{ Marital status } \\
\hline Married & 265 & 70.67 \\
\hline Single & 54 & 14.40 \\
\hline Divorced & 25 & 6.67 \\
\hline Widowed & 31 & 8.23 \\
\hline \multicolumn{3}{|l|}{ Residence } \\
\hline Rural & 125 & 33.33 \\
\hline Urban & 250 & 66.67 \\
\hline \multicolumn{3}{|l|}{ Educational level } \\
\hline Uneducated & 106 & 28.27 \\
\hline Up to secondary & 112 & 29.87 \\
\hline Diploma and above & 157 & 41.87 \\
\hline \multicolumn{3}{|l|}{ Occupation } \\
\hline Housewife & 171 & 45.60 \\
\hline Merchant & 55 & 14.67 \\
\hline Employ & 109 & 29.07 \\
\hline Student & 40 & 10.67 \\
\hline \multicolumn{3}{|l|}{ Ethnicity } \\
\hline Amhara & 113 & 30.13 \\
\hline Oromo & 69 & 18.40 \\
\hline Agew & 30 & 8.00 \\
\hline Shinasha & 58 & 15.47 \\
\hline Gumuz & 26 & 6.93 \\
\hline Berta & 36 & 9.60 \\
\hline Mao & 19 & 5.07 \\
\hline Komo & 11 & 2.93 \\
\hline Others & 13 & 3.47 \\
\hline
\end{tabular}

employed were significantly associated with LBW $(\mathrm{AOR}=0.11 ; 95 \%$ CI 0.01-0.92) (Table 2).

\section{Association of obstetric history of mothers and newborn-related factors with $L B W$}

Mother who did not have ANC follow-up $(\mathrm{AOR}=3.45$; 95\% CI 1.25-9.55), mother who did not get iron tablet during pregnancy $(\mathrm{AOR}=4.06 ; 95 \%$ CI $1.31-12.61)$, malaria attack during pregnancy $(\mathrm{AOR}=4.28 ; 95 \% \mathrm{CI}$ $1.65-11.14)$, and anemia during pregnancy $(\mathrm{AOR}=2.69$; 95\% CI 1.03-7.01) are identified associated factors with LBW. Regarding neonatal-related factors, being preterm $(\mathrm{AOR}=4.15,95 \%$ CI 1.74-9.89) was associated with LBW (Table 3).

\section{Discussion}

Low birth weight prevalence varies in different geographical areas. Estimating the burden of LBW in the current study area was found to be relevant for the regional policy implementation and healthcare resources allocation. Accordingly, the prevalence of LBW was14.9\% (95\% CI 11.7-18.9). The finding of the current study was comparable with a study conducted in Tigray Ethiopia (14.6\%) [17], Gondar Ethiopia (17.4\%) [9], and southern Ethiopia (17.88\%) [18].

On the other hand, it was higher than other Ethiopian settings, like Axum (9.9\%) [11] and Jimma Ethiopia (11.02\%) [10]. This might be due to the current study setting was a hospital setting where many chronic cases were referred from other health institutions but the others were community-based studies. Besides, the variation might be due to in the current study area was not well accessible for comprehensive health programs [16] and further due to cultural issues, in which one of the ethnic groups "Gumuz" population health seeking behaviors are poor. Besides, in "Gumuz" ethnic group, pregnant woman give birth alone and/or get away from around the peoples. The high malaria burden in the study area might be attributed to a high prevalence of LBW.

The current finding also higher than the finding from other African settings, like Nigeria [7], the United States of America [19], and Canada [20]. The possible explanation might be due to the difference in the level of antenatal care follow-up, the burden of food insecurity, the educational status of the community, cultural malpractices, and the high burden of co-morbid illness in Ethiopia.

Below normal birth weight is associated with the infant, maternal and obstetric related or environment and behavioral factors. Gestational age, malaria attack during pregnancy, anemia during pregnancy, the absence of ANC follow-up, and absence of iron intake during pregnancy were associated with LBW.

Regarding gestational age, preterm neonates were 4.2 times more likely to be LBW than term neonates. This finding was in agreement with a study done in Bale Ethiopia [21]. This might be due to the fact that as the gestational age of the fetus is lowered, prematurity and inadequate production of subcutaneous fat is prevalent [22].

The absence of ANC follow-up during pregnancy was another variable. Women had not ANC follow-up were 3.5 times more likely to give LBW baby than women who had ANC follow-up. The possible reason might be due to, in those who had no ANC follow-up, unable to detect early major health problems, pregnancy danger sign, and cultural malpractices that can affect the birth outcome of the neonate [23]. The other possible 
Table 2 The association between LBW and maternal demographic characteristics in Assosa and Pawi hospitals, Northwest Ethiopia, 2018

\begin{tabular}{|c|c|c|c|c|c|c|}
\hline \multirow[t]{2}{*}{ Variable } & \multicolumn{2}{|c|}{ LBW } & \multicolumn{2}{|c|}{ NBW } & \multirow[t]{2}{*}{ Crude OR (95\% Cl) } & \multirow[t]{2}{*}{ AOR $(95 \% \mathrm{Cl})$} \\
\hline & No. & $\%$ & No. & $\%$ & & \\
\hline \multicolumn{7}{|l|}{ Maternal age (years) } \\
\hline $15-20$ & 8 & 14.29 & 32 & 10.03 & $1.59(0.68,3.71)$ & \\
\hline $20-35$ & 37 & 66.07 & 235 & 73.67 & 1 & \\
\hline$>35$ & 11 & 19.64 & 52 & 16.30 & $1.34(0.64,2.81)$ & \\
\hline \multicolumn{7}{|l|}{ Marital status } \\
\hline Married & 36 & 64.29 & 229 & 71.79 & 1 & \\
\hline Single & 10 & 17.86 & 44 & 13.79 & $1.45(0.67,3.13)$ & \\
\hline Divorced & 5 & 8.93 & 20 & 6.27 & $1.59(0.56,4.50)$ & \\
\hline Widowed & 5 & 8.93 & 26 & 8.15 & $1.22(0.44,3.39)$ & \\
\hline \multicolumn{7}{|l|}{ Residence } \\
\hline Rural & 20 & 35.71 & 105 & 32.92 & $1.13(0.63,2.05)$ & \\
\hline Urban & 36 & 64.29 & 214 & 67.08 & & \\
\hline \multicolumn{7}{|l|}{ Educational level } \\
\hline Uneducated & 20 & 35.71 & 86 & 26.96 & $3.09(1.41,6.75)$ & $1.06(0.22,5.06)$ \\
\hline Up to secondary & 25 & 44.64 & 87 & 27.27 & 1 & 1 \\
\hline Diploma and above & 11 & 19.64 & 146 & 45.77 & $3.81(1.79,8.13)$ & $1.72(0.46,6.43)$ \\
\hline \multicolumn{7}{|l|}{ Occupation } \\
\hline Housewife & 31 & 55.36 & 140 & 43.89 & 1 & 1 \\
\hline Merchant & 8 & 14.28 & 47 & 14.73 & $0.77(0.33,1.79)$ & $0.77(0.23,2.61)$ \\
\hline Employ & 2 & 3.57 & 107 & 33.54 & $0.08(0.02,0.36)$ & $0.11(0.01,0.92)$ \\
\hline Student & 15 & 26.79 & 25 & 7.84 & $2.71(1.28,5.73)$ & $1.03(0.24,4.38$ \\
\hline \multicolumn{7}{|l|}{ Ethnicity } \\
\hline Amhara & 16 & 28.57 & 97 & 30.41 & 1 & \\
\hline Oromo & 13 & 23.21 & 56 & 17.55 & $1.41(0.63,3.14)$ & \\
\hline Agew & 3 & 5.36 & 27 & 8.46 & $0.67(0.18,2.48)$ & \\
\hline Shinasha & 9 & 16.07 & 49 & 15.36 & $1.11(0.46,2.70)$ & \\
\hline Gumuz & 5 & 8.93 & 21 & 6.58 & $1.44(0.48,4.38)$ & \\
\hline Berta & 6 & 10.71 & 30 & 9.40 & $1.21(0.44,3.38)$ & \\
\hline Mao & 2 & 3.57 & 17 & 5.33 & $0.71(0.15,3.39)$ & \\
\hline Komo & 1 & 1.79 & 10 & 3.13 & $0.61(0.07,5.06)$ & \\
\hline Others & 1 & 1.79 & 12 & 3.76 & $0.51(0.06,4.16)$ & \\
\hline
\end{tabular}

explanation might be those mothers who had no ANC visit during pregnancy may not receive iron supplementation and counseling about lifestyle and nutrition like food diversification during pregnancy to nourish the fetus for better growth and development during fetal growth [23].

Those mothers had history of malaria attack during pregnancy were 4.3 times more likely to deliver LBW baby than mothers had no history of malaria attack during pregnancy. This result is consistent with a study done in Gondar Ethiopia [9] and sub-Saharan Africa [24]. This might be due to long-standing infections during pregnancy has a direct effect to limit fetal growth.
One of the pathological effects of malaria is prematurity. This is due to placental infection with malaria causes the placenta to carry antibodies, cytokines, and macrophages which later causes early initiation of labor [25].

This study found anemia was one of the risk factors of LBW. Anemic mothers had 2.7 times more likely of getting a LBW baby than non-anemic mothers. This finding is in agreement with a study done in Sudan [26]. This is because the lack of hemoglobin due to anemia leads to impaired nutrient and oxygen transport to the fetus through the maternal placenta and the normal fetal growth in the utero may compromise as a result. Moreover, anemia is one of the chronic outcomes of 
Table 3 The association between LBW and maternal obstetric and neonate-related factors in Assosa and Pawi hospitals, Northwest Ethiopia, 2018

\begin{tabular}{|c|c|c|c|c|c|c|}
\hline \multirow[t]{2}{*}{ Variable } & \multicolumn{2}{|c|}{ LBW } & \multicolumn{2}{|c|}{ NBW } & \multirow[t]{2}{*}{ Crude OR $(95 \% \mathrm{Cl})$} & \multirow[t]{2}{*}{ AOR $(95 \% \mathrm{Cl})$} \\
\hline & No. & $\%$ & No. & $\%$ & & \\
\hline \multicolumn{7}{|l|}{ Parity } \\
\hline Multi-para & 41 & 73.21 & 239 & 74.92 & 1 & \\
\hline Primi-para & 15 & 26.79 & 80 & 25.08 & $1.09(0.57,0.08)$ & \\
\hline \multicolumn{7}{|l|}{ Maternal MUAC } \\
\hline$<23 \mathrm{~cm}$ & 9 & 16.07 & 41 & 12.85 & $1.30(0.59,2.85)$ & \\
\hline$\geq 23 \mathrm{~cm}$ & 47 & 83.93 & 278 & 87.15 & 1 & \\
\hline \multicolumn{7}{|l|}{ Pregnancy } \\
\hline Singleton & 48 & 85.71 & 270 & 84.64 & 1 & \\
\hline Multiple & 8 & 14.29 & 49 & 15.36 & $0.92(0.41,2.06)$ & \\
\hline \multicolumn{7}{|l|}{ History of abortion } \\
\hline Yes & 6 & 10.71 & 25 & 7.84 & $1.41(0.55,3.61)$ & \\
\hline No & 50 & 89.29 & 294 & 92.16 & 1 & \\
\hline \multicolumn{7}{|l|}{ Number of ANC } \\
\hline None & 33 & 58.93 & 42 & 13.17 & $9.46(5.07,17.65)$ & $3.45(1.25,9.55)$ \\
\hline One and above & 23 & 41.07 & 277 & 86.83 & 1 & 1 \\
\hline \multicolumn{7}{|l|}{ Iron tablet } \\
\hline Not taken & 27 & 48.21 & 25 & 7.84 & $14.64(7.09,30.22)$ & $4.06(1.31,12.61)$ \\
\hline Up to 1 month & 11 & 19.64 & 50 & 15.64 & $2.98(1.33,6.70)$ & $2.43(0.83,7.17)$ \\
\hline More than 2 months & 18 & 32.14 & 244 & 76.49 & 1 & 1 \\
\hline \multicolumn{7}{|l|}{ Malaria } \\
\hline Yes & 35 & 62.50 & 33 & 10.34 & $14.44(7.54,27.67)$ & $4.28(1.65,11.14)$ \\
\hline No & 21 & 37.50 & 286 & 89.66 & 1 & 1 \\
\hline \multicolumn{7}{|l|}{$\mathrm{PIH}$} \\
\hline Yes & 3 & 5.36 & 14 & 4.39 & $1.23(0.34,4.4)$ & \\
\hline No & 53 & 94.64 & 305 & 95.61 & 1 & \\
\hline \multicolumn{7}{|l|}{ Anemia } \\
\hline Yes & 28 & 50.00 & 37 & 11.60 & $7.62(4.08,14.25)$ & $2.69(1.03,7.01)$ \\
\hline No & 28 & 50.00 & 282 & 88.40 & 1 & 1 \\
\hline \multicolumn{7}{|l|}{ Previous LBW } \\
\hline Yes & 7 & 12.50 & 29 & 9.09 & $1.43(0.59,3.44)$ & \\
\hline No & 49 & 87.50 & 290 & 90.91 & 1 & \\
\hline \multicolumn{7}{|l|}{ Confirmed DM } \\
\hline Yes & 1 & 1.79 & 6 & 1.88 & $0.95(0.11,8.03)$ & \\
\hline No & 55 & 98.21 & 313 & 98.12 & 1 & \\
\hline \multicolumn{7}{|l|}{ Maternal weight } \\
\hline$<50 \mathrm{~kg}$ & 18 & 32.73 & 32 & 10.09 & $4.33(2.21,8.48)$ & $2.37(0.89,6.35)$ \\
\hline$\geq 50 \mathrm{~kg}$ & 38 & 67.27 & 287 & 89.91 & 1 & 1 \\
\hline \multicolumn{7}{|l|}{ Maternal height } \\
\hline$<1.50 \mathrm{~m}$ & 8 & 14.29 & 34 & 10.66 & $1.40(0.61,3.20)$ & \\
\hline$\geq 1.50 \mathrm{~m}$ & 48 & 85.71 & 285 & 89.34 & 1 & \\
\hline \multicolumn{7}{|l|}{ Substance use } \\
\hline Yes & 0 & 0.00 & 0 & 0.00 & & \\
\hline No & 56 & 14.93 & 319 & 85.07 & & \\
\hline \multicolumn{7}{|l|}{ Maternal abuse } \\
\hline Yes & 0 & 0.00 & 0 & 0.00 & & \\
\hline No & 56 & 14.93 & 319 & 85.07 & & \\
\hline
\end{tabular}


Table 3 (continued)

\begin{tabular}{|c|c|c|c|c|c|c|}
\hline \multirow[t]{2}{*}{ Variable } & \multicolumn{2}{|l|}{ LBW } & \multicolumn{2}{|c|}{ NBW } & \multirow[t]{2}{*}{ Crude OR $(95 \% \mathrm{Cl})$} & \multirow[t]{2}{*}{ AOR $(95 \% \mathrm{Cl})$} \\
\hline & No. & $\%$ & No. & $\%$ & & \\
\hline \multicolumn{7}{|c|}{ Gestational age (weeks) } \\
\hline$<37$ & 32 & 57.14 & 57 & 17.87 & $6.13(3.36,11.19)$ & $4.15(1.74,9.89)$ \\
\hline$\geq 37$ & 24 & 42.86 & 262 & 82.13 & 1 & 1 \\
\hline \multicolumn{7}{|c|}{ Sex of neonate } \\
\hline Male & 20 & 35.71 & 172 & 53.92 & 1 & 1 \\
\hline Female & 36 & 64.29 & 147 & 46.08 & $2.11(1.17,3.80)$ & $1.76(0.75,4.12)$ \\
\hline
\end{tabular}

systemic infections, which had a direct effect on the intrauterine growth retardation [27].

Mothers who did not take iron during pregnancy were 4.1 times more likely of getting LBW baby than who took iron. A study in India [28] was agreed with this finding. Iron and folic acid can prevent the occurrence of anemia and has a positive effect on the supplementation of oxygen and nutrient to the fetus. The absence of utilizing iron and folic acid contribute to poor organ development [29]. Besides, according to the current study, mothers being employed either government or other private sectors were $89 \%$ protective to LBW.

This study found that the prevalence of LBW was still high compared with WHO goal by 2025 which is a $3 \%$ reduction every year from 2012 to 2025 . Being preterm, lack of ANC follow-up, malaria attack during pregnancy, lack of iron supplementation, and employed mothers were associated factors of LBW.

\section{Limitation}

This study shares the limitation of cross-sectional study design and therefore, it does not show the seasonal variation of LBW.

\section{Abbreviations}

ANC: ante-natal care; AOR: adjusted odds ratio; EDHS: Ethiopian Demographic and Health Survey; LBW: low birth weight; MUAC: Mid Upper Arm Circumference; PIH: pregnancy induced hypertension; WHO: World Health Organization.

\section{Authors' contributions}

WK worked on designing the study, training the data collectors, supervising the data collectors, interpreting the result, preparing the manuscript. NT and $A E$ participated on designing the study, critically reviewing the study, interpreting the result, and preparing the manuscript. All authors read and approved the final manuscript.

\section{Author details}

${ }^{1}$ Department of Pediatric and Child Health Nursing, College of Health Sciences, Assosa University, Asosa, Ethiopia. ${ }^{2}$ Department of Pediatric and Child Health Nursing, School of Nursing, College of Medicine and Health Sciences, University of Gondar, Gondar, Ethiopia.

\section{Acknowledgements}

The authors acknowledge the Assosa University and the University of Gondar, Ethiopia for its financial support.

\section{Competing interests}

The authors declare that they have no competing interests.

Availability of data and materials

Data will be available upon request from the corresponding author.

Consent to publication

Not applicable.

\section{Ethical approval and consent to participate}

Ethical clearance was obtained from an Institutional review committee of the School of Nursing, College of Medicine and Health Sciences, University of Gondar. Permission letter was obtained from each hospital administration. Verbal consent was also taken from mothers after the ethics committee approved it. Whenever participants age $<18$ years, consent was obtained both from study participant and their mother.

Funding

Not applicable.

\section{Publisher's Note}

Springer Nature remains neutral with regard to jurisdictional claims in published maps and institutional affiliations.

Received: 19 July 2018 Accepted: 20 August 2018

Published online: 25 August 2018

\section{References}

1. OECD. Better policies for better lives-Social policy division: directorate of employment, labour and social affairs; 2017. http://www.oecd.org/. Accessed 11 Mar 2018

2. Lawn JE, Gravett MG, Nunes TM, Rubens CE, Stanton C. Global report on preterm birth and stillbirth (1 of 7): definitions, description of the burden and opportunities to improve data. BMC Pregnancy Childbirth. 2010;10(1):S1.

3. Hazzani FA, et al. Short-term outcome of very low-birth-weight infants in a tertiary care hospital in Saudi Arabia. Ann Saudi Med. 2011;31(6):581-5

4. World Health Organization. WHA global nutrition targets 2025: low birth weight policy brief. 2014. http://www.who.int/nutrition/topics/globaltarg ets_lowbirthweight_policybrief.pdf. Accessed 13 May 2018.

5. Brief $\mathrm{KCl}$. Preventing low birthweight. Baltimore: Annie E. Casey Foundation; 2009.

6. Koirala AK, Bhatta D. Low-birth-weight babies among hospital deliveries in Nepal: a hospital-based study. Int J Women's Health. 2015;7:581.

7. Oladeinde HB, Oladeinde OB, Omoregie R, Onifade AA. Prevalence and determinants of low birth weight: the situation in a traditional birth home in Benin City, Nigeria. Afr Health Sci. 2015:15(4):1123-9.

8. Muchemi OM, Echoka E, Makokha A. Factors associated with low birth weight among neonates born at Olkalou District Hospital, Central Region, Kenya. Pan Afr Med J. 2015;20:108. 
9. Zenebe K, Awoke T, Birhan N. Low birth weight \& associated factors among newborns in Gondar town, North West Ethiopia: institutional based cross-sectional study. Indo Glob J Pharm Sci. 2014;4(2):74-80.

10. Gebremariam A. Factors predisposing to low birth weight in Jimma hospital southwestern Ethiopia. East Afr Med J. 2005;82(11):554-8.

11. Teklehaimanot N, Hailu T, Assefa H. Prevalence and factors associated with low birth weight in Axum and laelay maichew districts, North Ethiopia: a comparative cross-sectional study. Int J Nutr Food Sci. 2014;3(6):560-6.

12. Tema T. Prevalence and determinants of low birth weight in Jimma Zone, Southwest Ethiopia. East Afr Med J. 2006;83(7):366.

13. Badshah S, Mason L, McKelvie K, Payne R, Lisboa PJ. Risk factors for low birthweight in the publichospitals at Peshawar, NWFP-Pakistan. BMC Public Health. 2008;8(1):197.

14. Central Statistical Agency (CSA) [Ethiopia] and ICF. Ethiopia demographic and health survey 2016. Rockville: CSA and ICF; 2016. p. 2016.

15. Benishangul-Gumuz Regional state REDD + design: a regional model for REDD: Ethiopia. 2017. http://www.et.undp.org/content/ethiopia/en/ home/library/environment_energy/CommissionedStudy.html. Accessed 7 Feb 2018

16. Central Statistical Agency (CSA) [Ethiopia] and ICF. Ethiopia demographic and health survey 2016. Addis Ababa, Ethiopia, and Rockville, Maryland, USA: CSA and ICF. https://dhsprogram.com/pubs/pdf/FR328/FR328.pdf. Accessed 21 Feb 2018.

17. Gebremedhin M, Ambaw F, Admassu E, Berhane H. Maternal associated factors of low birth weight: a hospital-based cross-sectional mixed study in Tigray, Northern Ethiopia. BMC Pregnancy Childbirth. 2015;15:222.

18. Wado YD, Afework MF, Hindin MJ. Effects of maternal pregnancy intention, depressive symptoms and social support on risk of low birth weight: a prospective study from southwestern Ethiopia. PLoS ONE. 2014;9(5):e96304
19. Martin J, Hamilton B, Osterman m et al. National Vital Statistics Reports. 2017;66:1.

20. Statistics Canada. Low birthweight newborn in Canada: health fact sheet, 2000 to 2013. http://www150.statcan.gc.ca. Accessed 3 June 2018.

21. Demelash H, Motbainor A, Nigatu D, Gashaw K, Melese A. Risk factors for low birth weight in Bale zone hospitals, South-East Ethiopia: a case-control study. BMC Pregnancy Childbirth. 2015;15(1):264.

22. Kliegman $\mathrm{R}$, et al. Nelson textbook of pediatrics. 20th ed. Phialdelphia: Elsevier; 2016.

23. Zeleke BM, Zelalem M, Mohammed N. Incidence and correlates of low birth weight at a referral hospital in Northwest Ethiopia. Pan Afr Med J. 2012;12(1):4.

24. Guyatt HL, Snow RW. Impact of malaria during pregnancy on low birth weight in sub-Saharan Africa. Clin Microbiol Rev. 2004;17(4):760-9.

25. Ismail MR, Ordi J, Menendez C, Ventura PJ, Aponte JJ, Kahigwa E, et al Placental pathology in malaria: a histological, immunohistochemical, and quantitative study. Hum Pathol. 2000;31(1):85-93.

26. Elhassan EM, Abbaker AO, Haggaz AD, Abubaker MS, Adam I. Anaemia and low birth weight in Medani, Hospital Sudan. BMC Res Notes. 2010;3(1):181.

27. McClure EM, Goldenberg RL, Dent AE, Meshnick SR. A systematic review of the impact of malaria prevention in pregnancy on low birth weight and maternal anemia. Int J Gynecol Obstet. 2013;121(2):103-9.

28. Muthayya S. Maternal nutrition and low birth weight-what is really important. Indian J Med Res. 2009:130(5):600-8.

29. Ismail IM, Venugopalan P. Case-control study on risk factors of low birth weight in a tertiary care hospital, Kerala. Ann Community Health. 2016;4(3):5-12
Ready to submit your research? Choose BMC and benefit from:

- fast, convenient online submission

- thorough peer review by experienced researchers in your field

- rapid publication on acceptance

- support for research data, including large and complex data types

- gold Open Access which fosters wider collaboration and increased citations

- maximum visibility for your research: over $100 \mathrm{M}$ website views per year

At $\mathrm{BMC}$, research is always in progress.

Learn more biomedcentral.com/submissions 